\title{
Multi-plasmid clash in a bacterial community: plasmid viability depends on the ecological setting of hosts
}

\author{
Cindy Given ${ }^{1}$, Reetta Penttinen ${ }^{1,2}$, Matti Jalasvuori ${ }^{1^{*}}$
}

${ }^{1}$ University of Jyväskylä, Department of Biological and Environmental Science, Nanoscience Center, Survontie 9C, Jyväskylä, Finland

${ }^{2}$ Department of Biology, FI-20014 University of Turku, Turku, Finland

*Corresponding author: Matti Jalasvuori, Survontie 9C, Ambiotica B2, Department of Biological and Environmental Science, Nanoscience Center, University of Jyväskylä. Tel: +358504135092 , email: matti.jalasvuori@jyu.fi 


\begin{abstract}
Plasmids are genetic elements that disperse horizontally between different strains and species of bacteria and a major factor in the dissemination of virulence factors and antibiotic resistance. Understanding the ecology of plasmids has a notable anthropocentric value and therefore the interactions between bacterial hosts and individual plasmids have been studied in detail. However, bacterial systems often carry multiple genetically distinct plasmids, but dynamics of these multiplasmid "clashes" has remained unstudied. Here, we set to investigate the survival of 11 mobilizable or conjugative plasmids in five different ecological settings. The key incentive was to determine whether plasmid dynamics are reproducible and whether there are trade-offs in plasmid fitness that stem from the ecological situation of their initial hosts. Growth rates and maximum population densities increased in all communities and treatments over the 42-day evolution experiment although plasmid contents at the end varied notably. We show that large multiresistance conferring plasmids are unfit when the community also contains smaller plasmids with fewer resistance genes. This suggests that restraining the use to few antibiotics can make bacterial communities sensitive to others. The hosts also appear to react to the presence of multiple genetically different plasmids by enhancing fimbriae production instead of alleviating costs of individual plasmids. In general, the survivors of the here-studied multi-plasmid clash are significantly affected by the presence or absence of antibiotic selection and plasmid-free hosts of varying fitness. Therefore, these trade-offs in different settings can explain for example why some resistance plasmids have an advantage during a rapid proliferation of antibiotic sensitive pathogen whereas others dominate in alternative situations.
\end{abstract}

Keywords: plasmid ecology, antibiotic resistance, multi-resistance, plasmid evolution. 


\section{Introduction}

Bacterial cells serve as vehicles for various types of genetic replicators. In addition to chromosomes, these include transposing elements, plasmids, conjugative elements and viruses. Many of these replicators contain genes that can entirely dictate whether the hosting cellular vehicle (host) prevails in its present environment. For instance, replicators such as plasmids can contain antibiotic resistance genes that protect the host from drugs whereas viruses may directly destroy its host in order to spread the virus to the surrounding community (Jalasvuori and Koonin, 2015; Cairns et al., 2018). Both examples play a role in the antibiotic resistance crisis as plasmids disseminate the resistance phenotype and viruses have been championed to provide a cure for these antibiotic resistant bacteria (Furfaro et al., 2018; Decano et al., 2020). Overall, genetic replicators provide a framework for dissecting bacterial communities not only into cells of particular species with defined genetic contents but also into an interacting network of genetic entities (Jalasvuori and Koonin, 2015) and, arguably, evolutionary ecology of bacterial systems is also ecology of genetic replicators (Jalasvuori, 2012).

Plasmids are common genetic molecules of bacteria that (usually) replicate separately from the host chromosome (Norman et al., 2009). Plasmids are of notable anthropocentric importance due to their clinically relevant features, mainly antibiotic resistance and virulence factors (Lopatkin et al., 2017; Pilla and Tang, 2018). The presence of a (conjugative) plasmid in a particular strain can therefore both translate into the development of a disease and treatment failure. Conjugative plasmids encode a machinery that facilitates the transfer of the element into surrounding bacterial cells (Virolle et al., 2020). Mobilizable plasmid utilize these machineries to hitchhike along the way and disperse from one cell to another (Smillie et al., 2010). Among gram-negative pathogens, conjugative and mobilizable plasmids are the most common genetic replicators mediating multi-drug resistance (Carattoli, 2009; Partridge et al., 2018; Ruotsalainen et al., 2020).

Bacteria carry various types of plasmids that can be divided into incompatibility groups according to their capability to stably coexist in a single cell line. The general prevalence of plasmids has been puzzling to explain in the absence of selection for plasmid-carried genes, since in new hosts, plasmids often induce fitness costs (Carroll and Wong, 2018). These costs, however, may be rapidly alleviated by adaptive mutations (Dahlberg and Chao, 2003; Loftie-Eaton et al., 2017; Carroll and Wong, 2018). Conjugation rates also differ and the plasmid-associated costs to host fitness may also be balanced by their ability to invade surrounding cells (Lopatkin et al., 2017). In certain conditions such as under active predation by protozoa, plasmid survival appears to be dependent on their ability to conjugate (Cairns et al., 2016). Adaptation to specific plasmids can also render bacteria to 
become more permissive to other plasmids and the evolved plasmids, respectively, to be of lesser burden in alternative hosts (Harrison and Brockhurst, 2012; Loftie-Eaton et al., 2017). Different plasmids that have adapted to hosts of different bacterial species can come in contact later on and form successful novel plasmid combinations (Jordt et al., 2020; Alonso-Del Valle et al., 2021) and hence form new multi-resistant strains. Altogether, these studies draw a picture in which several factors contribute to the means by which plasmids and their hosts can form a stable long-term companionship. These factors together may resolve the so-called plasmid-paradox - in other words, explain why plasmids do not disappear when we withdraw the selection for specific plasmid-carried genes (as discussed by Carroll and Wong, 2018).

In reality, however, bacterial cells are often in an environment where multiple plasmids are continuously present and new plasmids migrate in within new hosts. Extended spectrum betalactamase producing plasmids identified from hospital settings are substantially diverse in their specific genetic characteristics as well as in their incompatibility groups and mobility types (Carattoli, 2009; Weingarten et al., 2018). Therefore, bacteria face situations where a variety of plasmids clash together to compete within host cells of close proximity (Bedhomme et al., 2017). Many basic questions in this domain remain mostly unstudied. Are there, for example, characteristics that make certain plasmids outcompete others during a multi-plasmid clash, and if so, how stochastic are these dynamics? Are there specific adaptations in the host in a situation where multiple genetically different plasmids occupy the community in comparison to often-studied situations where adaptations can focus on alleviating costs of singular plasmids (Bedhomme et al., 2017)? Is there always a single winner in a certain set of plasmids, or can the winner be dependent on the ecological setting of the host? Indeed, new plasmid-free bacterial hosts may either form within the community as some hosts lose plasmids or they may migrate in from other environments. These new migrants may also have higher fitness than members of the original community, and hence dispersal to new hosts can become essential for survival. To our knowledge, no studies have investigated the dynamics of such multi-plasmid clashes with more than three different plasmids and rarely in alternating ecological conditions. As such, exploring the answers to these questions served as an incentive for this study.

Here we set to investigate a set of plasmids with varying characteristics in differing ecological settings. Total of eleven different plasmids originating from clinical isolates were transferred to isogenic background (Escherichia coli) in their natural combinations and then subjected together to a 42-day long serial co-culture experiment in five different ecological settings (such as in the presence of migrating bacteria and antibiotics). The results show that some plasmids prevail in specific conditions while disappear in others. The host adaptation may be a response to several 
genetically different plasmids instead of being a specific response to one or a few. Overall, there appears to be trade-offs that may play a role in the success of some plasmids, e.g., in the presence of hosts with higher fitness.

\section{Results}

We set up a serial culture microcosm experiment where each system was seeded with 11 plasmids that originated from extended-spectrum beta-lactamase (ESBL) encoding Escherichia coli strains in addition to a well-characterized conjugative plasmid RP4. The plasmids were transferred in their natural combinations to laboratory E. coli K-12 strain HMS174 in order to even out the competitive advantages that the original hosts. Some of the studied plasmids are conjugative and some are mobilizable (indicating that they are transferred along with a conjugative plasmid). In all plasmid combinations, at least one of the plasmids encode a beta-lactamase that provides resistance to betalactam antibiotics. Plasmid RP4 was included as it has been utilized in various studies where RP4encoded conjugation machinery has been employed to deliver CRISPR-systems to antibiotic resistant bacteria (Bikard et al., 2014; Ruotsalainen et al., 2019). As such, RP4's capability to compete amongst ESBL-plasmids provides estimates for its potential to modify bacterial communities with any introduced CRISPR-tools. However, RP4 contained a kanamycin resistance gene, which due to the experimental design, had to be inactivated prior to the microcosm experiments. Plasmids and their key features are listed in Table 1.

The plasmid-harbouring bacterial strains were mixed together for the microcosms that modelled five different ecological conditions (Figure 1). Each microcosm was refreshed 41 times, resulting in roughly 320 bacterial generations. Each experimental condition was carried out in four independent replicates. In the first setup, bacteria were cultivated and refreshed as a community (referred with $\mathrm{C}$ as in community). In the second setup, the community (CA, community + ampicillin) was subjected to continuous beta-lactam selection (thus representing an environment during treatment). In the third setup (CM, community + migration), bacterial community is continuously supplemented with plasmid-free hosts that can be invaded by the plasmids. In the fourth setup (CMK, community + migration + kanamycin), community is continuously introduced with migrating bacteria that have higher fitness than the original plasmid-hosts in an attempt to model the presence of rapidly proliferating plasmid-free pathogen. In the fifth setup (CMKA, community + migration + kanamycin + ampicillin), the community is treated with an antibiotic in the presence of an antibiotic-susceptible pathogen which could restore its full replication rate by receiving a resistance plasmid from the resistant community. 
We measured the growth rates and maximum population densities for individual plasmid-hosting strains as well as for the evolved communities (Figure 2). All plasmids had non-significant effects on the replication rate of the hosts (Figure 2A). During the course of the experiment, the growth rate of the community increased significantly in all conditions (Figure 2B). Interestingly, the presence of plasmids increased the maximum population densities (yield) (Figure 2C). Evolved communities also showed increase in yield compared to the starting point (Figure 2D). Kanamycin concentration utilized in the experiment was selected for the kanamycin-resistant strain, HMS174(pET24), to have both higher replication rate and density compared to other strains in order to model the presence of higher-fitness plasmid-free host. We also measured the conjugation rates for all plasmid-harbouring hosts by their ability to transfer the beta-lactamase resistance to a susceptible recipient (Table 2). While this does not reveal the transfer rates for non-resistance plasmids, previous study with these plasmids indicated that all plasmids were co-transferred together (Mattila et al., 2016).

Tracking the abundance of multiple plasmids with no specific selective genes can be challenging. As such, we employed quantitative polymerase chain reaction (qPCR) with specific primers against each plasmid (excluding pEC14pl2 and pEC15pl1 that were almost identical and hence were amplified with a single primer pair). Primer sequences and primer analysis are presented in Supplementary data 1. Total DNA was isolated at five time-points (1, 14, 32, 35 and 42 days) during the serial culture experiment and the relative quantity of each plasmid was determined against 16S rRNA genetic marker. qPCR measurements for each plasmid were conducted in three replicates. Figures 3 and 4 represent the evolution of plasmid prevalence over time (see Supplementary data 1 for original data). The majority of the eleven plasmids behaved similarly in all independent replicates within a particular experimental setup. However, pEC13 disappeared in all but one CA-replicate where it was well-represented, and pEC14pl3 disappeared in two CAreplicates and in one CM-replicate. This nevertheless suggests that plasmid-dynamics are generally consistent in a given ecological setting. Table 3 summarizes the behaviour of each plasmid in different setups.

We took a closer look at general features of plasmids in each of the ecological conditions to reveal characteristics that may be advantageous for plasmid survival (Table 4). Mobilizable plasmids can be grouped with MOB-classification system that bases its groups on relaxase genes (GarcillánBarcia et al., 2009). Relaxase itself is responsible for both initiating and terminating conjugative transfer of a plasmid. Conjugative plasmids can also be classified by the protein complex that mediates the mating pair formation (MPF) with a recipient cell (Schröder and Lanka, 2005). In C, most of the plasmids with MOBP persisted in the system while all except one plasmid with MOBF disappeared ( $p=0.001,2$-way ANOVA, post-hoc: Tukey HSD). In CA, plasmids with MOBP were 
more abundant than MOBF ( $\mathrm{p}=0.001$, 2-way ANOVA, post-hoc: Tukey HSD). In CA, all plasmids with MPFI persisted in the system while most or half of plasmids with MPFT and MPFF disappeared from the system ( $\mathrm{p} \leq 0.01,2$-way ANOVA, post-hoc: Tukey HSD). In CM, all plasmids with MPFI persisted in the system while plasmids with MPFT and MPFF generally decreased and disappeared from the system ( $\mathrm{p} \leq 0.01,2$-way ANOVA, post-hoc: Tukey HSD). In $\mathrm{CM}$, all except one of plasmids with MOBF were lost from the system while most plasmids with MOBP persisted ( $\mathrm{p}=0.005$, 2-way ANOVA, post-hoc: Tukey HSD). In CMK, all plasmids with MPFI and MPFT persisted in the system while most of plasmids (except pEC13) with MPFF disappeared, however, statistically, MPFI was more abundant than MPFF ( $p=0.001$, 2-way ANOVA, post-hoc: Tukey HSD) and MPFT $(\mathrm{p} \leq 0.01)$ but there was no difference between MPFF and MPFT ( $\mathrm{p}=0.621)$. In CMKA, all plasmids with MPFI and MPFT persisted in the system while most of the plasmids (except pEC13) with MPFF disappeared from the system ( $\leq \leq 0.01$, 2-way ANOVA, post-hoc: Tukey HSD). Here, MPFI was significantly more abundant than MPFF ( $\mathrm{p} \leq$ $0.01)$ and MPFT $(p \leq 0.01)$, but there was no difference between MPFT and MPFF $(p=1.000)$. In CMKA, no significant difference was observed among mobility groups ( $p=0.142,2$-way ANOVA, post-hoc: Tukey HSD). It must be noted that, while there are potentially relevant benefits in different MOB and MPF-systems in different conditions, the plasmids vary in multiple characteristics and hence these results should be approached very cautiously.

We also investigated potential evolutionary changes in the plasmids. Sequencing of the end-point communities revealed some mutations that repeatedly appeared during the serial culture experiment. Most of the mutations in plasmids were located in non-coding regions or genes with unknown functions, excluding pEC3pl1 in which mutations within the gene for conjugal transfer protein $\mathrm{V}$ (TraV) appeared in multiple communities (Figure 5). Genetic changes in non-coding regions were close to transposases or shufflon regions that are known to be less stable due to continuous DNA "shuffling" (Brouwer et al., 2019). Bacterial host consistently accumulated mutations in genes for type 1 fimbriae regulatory protein (FimE) and in certain conditions (CM) a single nucleotide variant in gene for RecA (Figure 6). The low number of mutations in CMKA community is likely to derive from the continuous supplement of non-evolved HMS174 that had higher fitness compared to plasmid-harbouring strains. This produced constant migration of naïve mutation-free host that possessed advantageous non-transmissible plasmid pET24. No mutations in four conjugative plasmids (pEC13, pEC14pl3, pEC16pl2 and RP4) and pET24 were detected in any of replicate communities. 


\section{Discussion}

Plasmids are ubiquitous genetic elements of bacteria. They are responsible for several notable phenotypes of their hosts, such as antibiotic resistance or increased virulence. Arguably, these opportunistic genes that provide immense benefits in only specific conditions are likely to accumulate to horizontally transferring elements. This is because genes in mobile elements are most likely to find their way to the high-fitness hosts of the community (Carattoli, 2013; Jalasvuori and Koonin, 2015; Jordt et al., 2020). Nonetheless, not all plasmids have clearly opportunistic genes (Gama et al., 2018) and plasmids co-exist in different ecological settings where only certain plasmid-backbones may find success. The potential effects that these conditions have on the survivability or dominance of plasmids in the presence of multiple competitors, to our knowledge, have not been studied directly. We set to investigate how plasmids thrive in the presence and absence of selection for opportunistic genes (antibiotic resistance) when there is or is not a migrating plasmid-free host with higher or equal fitness available. The studied plasmids represent various incompatibility types, mobility groups and conjugation systems and hence resemble a situation where different plasmids clash in a shared community.

Certain plasmids were unable to survive regardless of the tested setup. Plasmid pEC14p11 disappeared in all experiments. It is by far the largest plasmid $(143 \mathrm{~kb})$ and hence a notable burden to the host in the absence of selection for one of its nine resistance genes. This supports the line of reasoning where those plasmids that have accumulated large number of opportunistic genes are more dependent on specific selection on plasmid-carried genes than smaller plasmids (Ruotsalainen et al., 2020). However, and similarly to pEC14p11, RP4 also disappeared from all communities despite of being relatively small in size $(60 \mathrm{~kb})$. RP4 is an IncP plasmid that has a wide-host-range and it had the highest conjugation rate of all the plasmids of this experimental setup. Yet, it caused a greater reduction in the total population density compared to other plasmid combinations and therefore in a serial culture experiment, it is likely to dilute out. However, fitness cost of RP4 has been shown to readily ameliorate in Pseudomonas sp. host after mutations in genes for accessory helicases (Loftie-Eaton et al., 2017). Similar helicases exist in E. coli used in the study, but no such mutations were observed at the end of the experiment. This suggests that, while mutations may alleviate costs, the presence of alternative plasmids that are initially less costly to the host and provide similar opportunistic genes (antibiotic resistance) are likely to rapidly outcompete maladapted plasmids and hence probably reduce the chances for ameliorative mutations to establish in the community. IncP plasmids are also noted to be rare among Enterobacterial hospital pathogens (Carattoli, 2009) and hence the observed inability to survive against more common (narrow-host range) plasmids (such as IncF and IncI) is expectable. If the system had alternative hosts besides $E$. 
coli, the variety of potential hosts (that are generally unsuitable for the here-used pEC-plasmids) may have allowed it to prevail (Hall et al., 2016; Gama et al., 2018). All other plasmids survived in at least some conditions.

The plasmids in this study were seeded into the experiment in their natural combinations. It could be anticipated that these plasmids had already adapted to coexistence in their original hosts. However, in only some setups pEC15 and pEC16 plasmids remained at similar levels throughout the experiment (although it must be noted that our quantification method did not allow determining whether they existed in the same cells). As such, previous co-existence appears to readily dissolve and potentially new plasmid-combinations form.

Interestingly, $\mathrm{pEC16p12}$ is a small mobilizable plasmid that encodes for a (putative) microcin that is lethal to surrounding cells unless it carries the plasmid. HMS174 with pEC16 inhibits the growth of HMS174 harbouring any of the other plasmid-combinations (data not shown). Intrinsically, it appears reasonable to expect that pEC16pl2 becomes dominant in the community. Nevertheless, preliminary experiments demonstrated that $\mathrm{pEC} 16 \mathrm{pl} 2$ does not replace other plasmids from the system even in the absence of antibiotics and, as such, we retained it in the experimental setup to evaluate the plasmid's long-term viability. Indeed, in the absence of simulated presence of a pathogen (i.e. sub-lethal kanamycin and kanamycin resistant E. coli), the amount of pEC16pl2 remained among the highest. However, the introduction of kanamycin and a kanamycin-resistant host (i.e. simulated proliferating pathogen) caused it to rapidly disappear. This indicates a clear trade-off where change in the ecological setting turns the plasmid's fitness completely around. The initially co-existing plasmid partner of pEC16p2 (i.e. pEC16pl1) was stable only in the refreshed community (C), suggesting that $\mathrm{pEC} 16 \mathrm{pl} 2$ prevalence in other systems was independent of pEC16pl1.

Plasmids are generally divided into incompatibility groups where two plasmids of the same type cannot coexist in a single cell line. Here, plasmid pEC13 and pEC14p13 both belong to IncFII and generally prevailed in only those cultures where the other was absent. pEC13 became the dominant IncFII plasmid in conditions where the simulated pathogen was present (CMK and CMKA) whereas pEC14p13 prevailed in others. Correspondingly, pEC16p11, pEC14p12 and pEC15pl1 are IncI1 plasmids, of which pEC16pl1 was prevalent in only community $\mathrm{C}$ whereas genetically indistinguishable plasmids pEC14pl2 and pEC15pl1 were prevalent in others. This suggests that plasmids of the same incompatibility group with similar size and overall genetic characteristics can have drastic differences in fitness in response to the ecological condition of their hosts.

Host chromosomes are known to adapt to plasmid presence, but former studies have focused on investigating the effects of singular plasmids (see e.g. Dahlberg and Chao, 2003; Yano et al., 2016; 
Loftie-Eaton et al., 2017). Here in an environment with 11 interacting mobilizable or conjugative plasmids (two of which were almost identical), the only consistently occurring mutations over 300 generations were observed within gene fimE. This gene is responsible for switching off fim operon and hence fimbriae production in E. coli (Abraham et al., 1985). FimE inactivating mutations therefore result in continuously active fimbriae operon. Fimbriae play key roles in E. coli pathogenicity, host immune responses and biofilm production (Decano et al., 2021). IncI1 and Fplasmids plasmids have been shown to encode pili that induce fimbriae-like phenotype in the host and pilin mutants have significantly lower conjugation rate compared to wild type (Dudley et al., 2006; Virolle et al., 2020). It is possible that fimE inactivation and hence constitutive fimbriae production is an adaptation to the general experimental conditions where the bacteria were cultivated. However, this is unlikely to be the case since evolution occurred outside of the host organism (no benefit for pathogenicity) and attachment to surfaces (Kallas et al., 2020) would have made cells less likely to be transferred to the fresh medium in the experimental setup where planktonic population was utilized to seed the next culture cycle. Given that majority of the plasmids here encode pili with (likely) comparable phenotypes to fimbriae, it is within reason to expect that the expression of chromosomally encoded fimbriae was under selection solely due to the large number of genetically different plasmids. In other words, the generation of fimbriae-like phenotype especially from chromosome instead of one of the several potential plasmids had a specific benefit for the host bacterium. Porse and colleagues (Porse et al., 2016) observed fimE mutation in a serial culture experiment with a single IncF-plasmid in only one of several evolved $E$. coli lineages. In the famous long-term evolution experiment, no such mutations were observed after 2000 to 20000 generations (Barrick et al., 2009). In both of these experiments, the culture conditions were roughly the same (i.e. $37^{\circ} \mathrm{C}$ temperature and shaking). Nevertheless, while the detailed study of this was beyond our resources, we cautiously hypothesize that those bacterial cells that produced more fimbriae over their contemporaries may be less prone to the invading plasmids that were present in the surrounding bacteria. These other bacteria may have encoded fimbriae-like pili mainly from plasmids. To clarify, fimbriae or pili were present in most cells nevertheless and there was a difference whether it was pili that initiates conjugation or if it was fimbriae encoded by the chromosome (that do not lead to conjugation). This chromosomal expression may have protected the bacterium from plasmid invasion and hence from the recently demonstrated acquisition-associated detrimental fitness effects (Prensky et al., 2021). Therefore, this selection might be observable only in conditions where several genetically different plasmids can simultaneously enter the host and no specific mutation in any of the plasmids or in the chromosome can shut them all down. 
Overall, the study shows that plasmids have trade-offs that allow them to outcompete their contemporaries only in certain conditions. The big multi-resistance-providing plasmids may require specific selection to remain viable in the presence of smaller competitors. This observation can be of importance, given that limiting the administration of multiple types of antibiotics reduces the selection for large plasmids like pEC14pl1 and hence may lead to their displacement with smaller plasmids with fewer resistance genes. On the other hand, broad host-range plasmids (like RP4) may serve as reservoirs of antibiotic resistance genes in non-pathogenic hosts in different environments from which they can supply resistances to relevant hosts (as noted by Loftie-Eaton and colleagues; Loftie-Eaton et al., 2017). In general, the absence of selection for plasmids via antibiotics did not have an effect on plasmid prevalence and hence removing antibiotics altogether does not seem to rapidly re-sensitize bacteria to drugs even in highly competitive situations where non-resistant, rapidly proliferating cells are present (i.e. CMK community). Multi-plasmid clashes are likely to occur in natural environments and under differing ecological settings. This work here provides one of the first overviews of the dynamics that occur during such multi-plasmid interaction and may illuminate situations where certain plasmids become over-represented over their contemporaries.

\section{Materials and methods}

\section{Bacterial strains, plasmids and culture conditions}

Bacterial strains and their plasmids are listed in Table 1. For initiating the community experiment, each strain was grown separately in $50 \mathrm{ml}$ tubes containing $5 \mathrm{ml}$ of Luria-Bertani broth (LB) (Bertani, 1951) with the appropriate antibiotic selection (either $150 \mu \mathrm{g} / \mathrm{ml}$ ampicillin or $25 \mu \mathrm{g} / \mathrm{ml}$ kanamycin) for overnight at $37^{\circ} \mathrm{C}$ with shaking $200 \mathrm{rpm}$. Due to experimental design, kanamycin gene had to be inactivated in plasmid RP4. This was done as described in Ruotsalainen et al., 2020. Briefly, a synthetic gene containing an inactivating mutation within kanamycin resistance gene was inserted with homological recombination in the RP4 plasmid using Red/ET Recombination (Gene Bridges) according to manufacturer's protocol. Kanamycin-sensitive phenotype was screened from the obtained colonies and the presence of the inactivating insertion verified with polymerase chain reaction. The mutated plasmid was transferred via conjugation to HMS174.

\section{Plasmid competition experiment}


Microcosm experiment was set up into five ecological settings (treatments) and named as C, CA, $\mathrm{CM}, \mathrm{CMK}$ and CMKA. At the start of the experiment (cycle 1; C1), $5 \mu$ l overnight $(\mathrm{o} / \mathrm{n})$ cultures of pEC strains and RP4 were added to a $50 \mathrm{ml}$ tube containing $5 \mathrm{ml}$ LB medium supplemented with appropriate antibiotics and/or bacterial culture according to the setup (see Table 5 and Figure 1). The cultures were grown at $37^{\circ} \mathrm{C}$ and aerated by slow agitating at $60 \mathrm{rpm}$ for 24 hours. The experiment was done with four identical replicates/treatment. After each cycle, $50 \mu 1$ of the culture ( $1 \%$ inoculation) was transferred to the fresh media, and in case of CM, CMK and CMKA, 5 ul of overnight cultivated migrant added. The cultures were serially propagated for 42 cycles.

\section{Sample collections and DNA extraction}

The samples were harvested after every 3 cycles in the first week and then, after every 7 cycles. One $\mathrm{ml}$ of each bacterial culture (in total 20 cultures; 5 setups x 4 biological replicates) was collected in $1.5 \mathrm{ml}$ tubes and stored at $-80^{\circ} \mathrm{C}$ for the DNA isolation. Additionally, the cultures were collected for the measuring of growth rate and yield. Here $1 \mathrm{ml}$ of each bacterial culture was mixed with $300 \mu$ l of sterile $87 \%$ glycerol in cryotubes and stored in $-80^{\circ} \mathrm{C}$.

The total DNA (genomic and plasmid) of all the samples from cycle 1, 14, 32, 35 and 42 were extracted with Wizard $®$ Genomic DNA purification kit (Promega) following the manufacturer's instructions. Qubit 3.0 fluorometer was used to determine the concentration of DNA using the dsDNA high sensitivity kit (Invitrogen, ThermoFisher Scientific).

\section{Quantitative PCR (qPCR) with plasmid specific primers}

The amount of each plasmid in the samples obtained from the community experiment was quantified with quantitative PCR (qPCR). Prior to this, each primer pair used in this experiment were optimized for their efficiency (Supplementary data 1). The crosscheck test with all other plasmids in this experiment was also performed to ensure the specificity (Supplementary data 1). qPCR was performed in triplicates for each sample. Final reaction volume of $20 \mu \mathrm{l}$ contained $1 x$ SsoAdvanced universal SYBR green supermix (Bio-Rad), $0.5 \mu \mathrm{M}$ of forward and reverse primers and $2 \mu \mathrm{l}$ of DNA template $(1 \mathrm{ng} / \mu \mathrm{l})$. The qPCR cycle program consisted of initial denaturation at $98^{\circ} \mathrm{C}$ for 3 minutes, followed by 40 cycles of denaturation at $98^{\circ} \mathrm{C}$ for 15 seconds and primer annealing - extension at $60^{\circ} \mathrm{C}$ or $65^{\circ} \mathrm{C}$ (depends on the primer pairs; Supplementary data 1) for 1 minute 15 seconds. All qPCR assays were performed in Bio-Rad CFX96 Touch $^{\text {TM }}$ Real-Time PCR Detection System (Bio-Rad). 
The amount of each plasmid at every time point (cycle 1, 14, 32, 35 and 42) for all treatments and all replicates was analyzed with CFX Maestro ${ }^{\mathrm{TM}} 1.1$ software (version 4.1.2433.1219) by normalization against $16 \mathrm{~S}$ rRNA using normalized expression mode from gene study function.

\section{Bacterial growth rate and yield}

A single colony of each original bacterial strain was inoculated into $5 \mathrm{ml}$ media containing appropriate antibiotics: LB medium without antibiotics for plasmid-free HMS174, LB medium supplemented with $150 \mu \mathrm{g} / \mathrm{ml}$ ampicillin for HMS174 carrying pEC plasmids and RP4, and LB medium supplemented with $25 \mu \mathrm{g} / \mathrm{ml}$ kanamycin for HMS174 carrying pET24. Cultures were grown at $37^{\circ} \mathrm{C}, 200 \mathrm{rpm}$, overnight. Prior to the measurement of growth rate (see below), $50 \mu 1$ of each culture was transferred into $5 \mathrm{ml}$ of new media and mixed thoroughly. $200 \mu \mathrm{l}$ of this inoculated media was transferred onto a honeycomb plate with four replicates/sample. All the strains were tested for growth under four different LB-based media: without antibiotics, with 150 $\mu \mathrm{g} / \mathrm{ml}$ ampicillin, with $2.5 \mu \mathrm{g} / \mathrm{ml}$ kanamycin, and with $150 \mu \mathrm{g} / \mathrm{ml}$ ampicillin and $2.5 \mu \mathrm{g} / \mathrm{ml}$ kanamycin.

Additionally, the growth rate and yield of bacterial communities at the beginning (cycle 1) and in the end of the experiment (cycle 42) from each treatment were measured. $50 \mu 1$ of thawed sample was transferred into $5 \mathrm{ml}$ of the media composition used in the serial culture experiment (Table 4). From this, $200 \mu \mathrm{l}$ was transferred into a honeycomb plate with four replicates/sample. The growth curves and maximum absorbance at $600 \mathrm{~nm}$ was measured with Bioscreen $\mathrm{C}$ MBR machine (Bioscreen, Oy Growth Curves Ab Ltd).

The maximum growth rates and yields of each strain were determined with Bioscreen C MBR machine (Bioscreen, Oy Growth Curves $\mathrm{Ab} \mathrm{Ltd}$ ) at $37^{\circ} \mathrm{C}$ with low shaking. The absorbance was measured at $\mathrm{OD}_{600}$ for 16 hours in 5-minute intervals. The maximum growth rate and yield were calculated from the data obtained from Bioscreen using Rstudio (version 1.1.456).

\section{Conjugation rate test}

HMS174 (pET24) was used as a recipient strain and all the strains with pEC plasmids and RP4 were the donor strains. All the strains were sub-cultured from frozen stock prior to the test.

A single colony of recipient strain was inoculated into $50 \mathrm{ml}$ falcon tube containing $5 \mathrm{ml} \mathrm{LB}$ medium supplemented with $25 \mu \mathrm{g} / \mathrm{ml}$ kanamycin whereas each of the donor strains was grown separately in $5 \mathrm{ml} \mathrm{LB}$ medium supplemented with $150 \mu \mathrm{g} / \mathrm{ml}$ ampicillin. All the cultures were grown at $37^{\circ} \mathrm{C}$ overnight, $200 \mathrm{rpm}$. Each one of the donors and recipient strain, a total of 6 different combinations, were then mixed at 1:1 volume ratio $(5 \mu \mathrm{leach})$ in a $50 \mathrm{ml}$ falcon tube containing 5 
$\mathrm{ml}$ LB medium without antibiotics. The test was done in four biological replicates/combination. The cell mixtures were then incubated at $60 \mathrm{rpm}, 37^{\circ} \mathrm{C}$ for 24 hours. After incubation, the cultures were serially diluted to the appropriate dilutions (from $10^{-2}$ to $10^{-6}$ ) and plated on LB agar with $150 \mu \mathrm{g} / \mathrm{ml}$ ampicillin and $25 \mu \mathrm{g} / \mathrm{ml}$ kanamycin. The plates were incubated overnight at $37^{\circ} \mathrm{C}$. Each strain without the conjugation was also plated as the negative control. The conjugation rate was calculated as colony-forming unit/ml (CFU/ml).

\section{Mutation mapping}

The DNA samples from the end-point of the experiment were used for preparation of sequencing library with NEB Next® ${ }^{\circledR}$ Ultra $^{\mathrm{TM}}$ DNA Library Prep Kit (Cat No. E7370L) and sequenced on Illumina NovaSeq 6000 platform with S4 flowcell (PE150).

After receiving the sequence data, the mapping of plasmid sequences to find possible mutations and to compare between treatments was performed with CLC Genomic Workbench software version 11 (Qiagen). First, the reference genomes of E. coli HMS174 and all the pEC plasmids, RP4 and pET24 were combined as a single reference file using Geneious Prime software version 2020.1.2 (Geneious). Then, the reference genomes and Illumina sequence reads of all the samples were imported into the workbench. The reads were then mapped to the references, followed by variant detection with $35 \%$ as a threshold for mutation and annotation. Finally, the data was exported to Microsoft Excel for further analysis.

\section{Statistical analysis}

All statistical analyses were performed using SPSS (version 26, IBM SPSS). Two-way analysis of variance (ANOVA) with Tukey HSD as post hoc was used to analyze the difference in growth rate and yield between strains and between communities under all treatments at the beginning and the end of the experiment. The conjugation rate was analyzed with one-way ANOVA, post hoc = Tukey HSD. P-values <0.05 were considered significant in all tests.

\section{References}

Abraham JM, Freitag CS, Clements JR, Eisenstein BI. An invertible element of DNA controls phase variation of type 1 fimbriae of Escherichia coli. Proc Natl Acad Sci U S A. 1985. 82:5724-7. doi: $10.1073 /$ pnas.82.17.5724. 
Carattoli A, Resistance Plasmid Families in Enterobacteriaceae, Antimicrobial Agents and Chemotherapy. 2009, 53: 2227-2238; doi: 10.1128/AAC.01707-08

Alonso-Del Valle, A., León-Sampedro, R., Rodríguez-Beltrán, J., DelaFuente, J., HernándezGarcía, M., Ruiz-Garbajosa, P., Cantón, R., Peña-Miller, R., \& San Millán, A. Variability of plasmid fitness effects contributes to plasmid persistence in bacterial communities. 2021. Nature communications, 12: 2653. doi: 10.1038/s41467-021-22849-y

Barrick, J., Yu, D., Yoon, S. et al. Genome evolution and adaptation in a long-term experiment with Escherichia coli. 2009. Nature 461, 1243-1247. doi: 10.1038/nature08480

Bikard D, Euler CW, Jiang W, Nussenzweig PM, Goldberg GW, Duportet X, Fischetti VA, Marraffini LA. Exploiting CRISPR-cas nucleases to produce sequence-specific antimicrobials. Nat Biotechnol. 2014. 32:1146-1150. doi:10.1038/nbt.3043.

Brouwer MSM, Jurburg SD, Harders F, Kant A, Mevius DJ, Roberts AP, Bossers A. The shufflon of IncI1 plasmids is rearranged constantly during different growth conditions. 2019. Plasmid 102:51-55.

Bedhomme S, Perez Pantoja D, Bravo IG. Plasmid and clonal interference during post horizontal gene transfer evolution. Mol Ecol. 2017. 26:1832-1847. doi: 10.1111/mec.14056.

Gama JA, Zilhão R, Dionisio F. Impact of plasmid interactions with the chromosome and other plasmids on the spread of antibiotic resistance. Plasmid. 2018. 99:82-88. doi: 10.1016/j.plasmid.2018.09.009.

Garcillán-Barcia MP, Francia MV, de la Cruz F. The diversity of conjugative relaxases and its application in plasmid classification. FEMS Microbiol Rev. 2009. 33:657-87. doi: 10.1111/j.15746976.2009.00168.x.

Schröder G, Lanka E. The mating pair formation system of conjugative plasmids-A versatile secretion machinery for transfer of proteins and DNA. 2005. Plasmid. 54:1-25. doi: 10.1016/j.plasmid.2005.02.001.

Bertani, G. Studies on Lysogenesis I. The Mode of Phage Liberation by Lysogeny Escherichia coli. 1951. J Bacteriol. 62: 293-300.

Cairns J, Jalasvuori M, Ojala V, Brockhurst M, Hiltunen T. Conjugation is necessary for a bacterial plasmid to survive under protozoan predation. 2016. Biology Letters. 12: 20150953

Carattoli, A. Resistance Plasmid Families in Enterobacteriaceae, Antimicrobial Agents and Chemotherapy. 2009. 53:2227-2238. doi: 10.1128/AAC.01707-08

Carattoli, A. Plasmids and the spread of resistance. 2013. International Journal of Medical Microbiology. 303: 298- 304 
Carroll AC, Wong A. Plasmid persistence: costs, benefits, and the plasmid paradox. 2018. Can J Microbiol. 64:293-304. doi: 10.1139/cjm-2017-0609.

Dahlberg C, Chao L. Amelioration of the cost of conjugative plasmid carriage in Eschericha coli K12. 2003. Genetics.165:1641-1649.

Decano, A. G., Tran, N., Al-Foori, H., Al-Awadi, B., Campbell, L., Ellison, K., Mirabueno, L. P., Nelson, M., Power, S., Smith, G., Smyth, C., Vance, Z., Woods, C., Rahm, A., \& Downing, T. Plasmids shape the diverse accessory resistomes of Escherichia coli ST131. 2020. Access microbiology, 3:acmi000179. doi: 10.1099/acmi.0.000179

Dudley EG, Abe C, Ghigo JM, Latour-Lambert P, Hormazabal JC, Nataro JP. An IncI1 plasmid contributes to the adherence of the atypical enteroaggregative Escherichia coli strain C1096 to cultured cells and abiotic surfaces. 2006. Infect Immun. 74:2102-14. doi: 10.1128/IAI.74.4.21022114.2006.

Furfaro LL, Payne MS, Chang BJ. Bacteriophage Therapy: Clinical Trials and Regulatory Hurdles. Front Cell Infect Microbiol. 2018. 23:376. doi: 10.3389/fcimb.2018.00376.

Garcillán-Barcia, M. P., Alvarado, A., and de la Cruz, F. Identification of bacterial plasmids based on mobility and plasmid population biology. 2011. FEMS Microbiol Rev. 35: 936-956

Jalasvuori, M. Vehicles, replicators, and intercellular movement of genetic information: evolutionary dissection of a bacterial cell. International Journal of Evolutionary Biology. 2012. 17. doi: 10.1155/2012/874153

Hall, J. P., Wood, A. J., Harrison, E. \& Brockhurst, M. A. Source-sink plasmid transfer dynamics maintain gene mobility in soil bacterial communities. 2016. Proc. Natl. Acad. Sci. USA. 113: 82608265

Harrison E, Brockhurst MA. Plasmid-mediated horizontal gene transfer is a coevolutionary process. 2012. Trends in Microbiology. 20: 262-267.

Jalasvuori, M., and Koonin, E. Classification of prokaryotic genetic replicators: between selfishness and altruism. 2015. Annals of the New York Academy of Sciences. 1341: 96-105. doi:10.1111/nyas.12696

Johnson, T.J., and Nolan, L.K. Pathogenomics of the Virulence Plasmids of Escherichia coli. 2009. Microbiol Mol Biol Rev. 73: 750-774. doi: 10.1128/MMBR.00015-09

Jordt, H., Stalder, T., Kosterlitz, O. et al. Coevolution of host-plasmid pairs facilitates the emergence of novel multidrug resistance. 2020. Nat Ecol Evol 4: 863-869.

Kallas P, Haugen HJ, Gadegaard N, Stormonth-Darling J, Hulander M, Andersson M, Valen H. Adhesion of Escherichia Coli to Nanostructured Surfaces and the Role of Type 1 Fimbriae. 2020. Nanomaterials. 10:2247. doi: 10.3390/nano10112247 
Loftie-Eaton, W., Bashford, K., Quinn, H. et al. Compensatory mutations improve general permissiveness to antibiotic resistance plasmids. 2017. Nat Ecol Evol. 1: 1354-1363.

Lopatkin, A. J., Meredith, H. R., Srimani, J.K., Pfeiffer, C., Durrett, R., and You, L. Persistence and reversal of plasmid-mediated antibiotic resistance. 2017. Nature Communications. 8: 1689

Mattila S, Ruotsalainen P, Ojala V, Tuononen T, Hiltunen T, Jalasvuori M. Conjugative ESBL plasmids differ in their potential to rescue susceptible bacteria via horizontal gene transfer in lethal antibiotic concentrations. 2017. J. Antibiot. 70:805-808. doi: 10.1038/ja.2017.41.

Norman, A., Hansen, L. H., and Sørensen, S. J. Conjugative plasmids: vessels of the communal gene pool. 2009. Philosophical transactions of the Royal Society of London. Series B, Biological sciences. 364: 2275-2289. doi: 10.1098/rstb.2009.0037

Partridge SR Kwong SM Firth N Jensen SO. Mobile genetic elements associated with antimicrobial resistance. 2018. Clinical Microbiology Reviews 31: 17.

Pilla, G., and Tang, C. M. Going around in circles: virulence plasmids in enteric pathogens. 2018. Nature Reviews Microbiology. 16: 484-495.

Porse A, Schønning K, Munck C, Sommer MO. Survival and Evolution of a Large Multidrug Resistance Plasmid in New Clinical Bacterial Hosts. 2016. Mol Biol Evol. 33: 2860-2873. doi: 10.1093/molbev/msw163.

Prensky, H., Gomez-Simmonds, A., Uhlemann, A. C., \& Lopatkin, A. J. Conjugation dynamics depend on both the plasmid acquisition cost and the fitness cost. 2021. Molecular systems biology, 17: e9913. doi: 10.15252/msb.20209913

Ruotsalainen P, Given C, Penttinen R, Jalasvuori M. Beta-Lactam Sensitive Bacteria Can Acquire ESBL-Resistance via Conjugation after Long-Term Exposure to Lethal Antibiotic Concentration. 2020. Antibiotics. 9: E296.

Ruotsalainen, P., Penttinen, R., Mattila, S., \& Jalasvuori, M. Midbiotics: conjugative plasmids for genetic engineering of natural gut flora. 2019. Gut microbes, 10: 643-653. doi: $10.1080 / 19490976.2019 .1591136$

Smillie, C., Garcillán-Barcia, M. P., Francia, M. V., Rocha, E. P. C., and de la Cruz, F. Mobility of Plasmids. 2010. Microbiology and Molecular Biology Reviews. 74: 434-452.

Virolle, C., Goldlust, K., Djermoun, S., Bigot, S., and Lesterlin, C. Plasmid Transfer by Conjugation in Gram-Negative Bacteria: From the Cellular to the Community Level. 2020. Genes, 11: 1239. doi: 10.3390/genes 11111239

Weingarten RA, Johnson RC, Conlan S, Ramsburg AM, Dekker JP, Lau AF, Khil P, Odom RT, Deming C, Park M, Thomas PJ; NISC Comparative Sequencing Program, Henderson DK, Palmore TN, Segre JA, Frank KM. Genomic Analysis of Hospital Plumbing Reveals Diverse Reservoir of 
Bacterial Plasmids Conferring Carbapenem Resistance. 2018. mBio. 9:e02011-17. doi: 10.1128/mBio.02011-17.

Yano H, Wegrzyn K, Loftie-Eaton W, Johnson J, Deckert GE, Rogers LM, Konieczny I, Top EM.

Evolved plasmid-host interactions reduce plasmid interference cost. 2016. Mol Microbiol. 101:743-

56. doi: 10.1111/mmi.13407. 


\section{TABLES AND TABLE LEGENDS}

Table 1. Plasmid-harboring strains used in the experiment

\begin{tabular}{|c|c|c|c|c|c|c|c|}
\hline Strain & Plasmid(s) & Inc type & $\begin{array}{c}\text { Mating pair } \\
\text { formation type }\end{array}$ & $\begin{array}{l}\text { Mobility } \\
\text { class }\end{array}$ & $\begin{array}{l}\beta \text {-lactamase } \\
\text { identified }\end{array}$ & Other resistance genes & References \\
\hline E. coli HMS 174 (plasmid-free) ${ }^{R i R}$ & - & - & - & - & - & - & - \\
\hline \multirow[t]{2}{*}{ E. coli $\mathrm{HMS} 174(\mathrm{pEC} 3)^{R i f R, A m p R}$} & pEC3pll & $\operatorname{IncB} / \mathrm{O} / \mathrm{K} / \mathrm{Z}$ & MPFI & MOBP & blaTEM-1C & strA, strB, sul2 & Mattila et al. 2017 \\
\hline & pEC3pl2 & IncI2 & MPFT & MOBP & - & - & Mattila et al. 2017 \\
\hline E. coli HMS $174\left(\mathrm{pEC13)}{ }^{\text {RifR,AmpR }}\right.$ & $\mathrm{pEC} 13$ & IncFII & MPFF & MOBF & blactX-M-14 & - & Mattila et al. 2017 \\
\hline \multirow[t]{3}{*}{ E. coli HMS174 (pEC14) ${ }^{\text {RifR,AmpR }}$} & pEC14p11 & $\begin{array}{l}\text { IncFII, IncQ1, IncP, } \\
\text { IncFIB }\end{array}$ & MPFF & MOBF & blaTEM-1B & $\begin{array}{l}\operatorname{str} A, \operatorname{str} B, \operatorname{aad} A 1, \operatorname{mph}(B), \text { sull, } \\
\operatorname{sul} 2, \operatorname{tet}(A), \operatorname{dfr} A 1\end{array}$ & Mattila et al. 2017 \\
\hline & pEC14p12 & IncII & MPFI & MOBP & - & - & Mattila et al. 2017 \\
\hline & pEC14p13 & IncFII & MPFF & MOBF & - & - & Mattila et al. 2017 \\
\hline \multirow[t]{2}{*}{ E. coli HMS174 (pEC15) ${ }^{\text {RifR,AmpR }}$} & pEC15p11 & IncIl & MPFI & МOBP & - & - & Mattila et al. 2017 \\
\hline & pEC15p12 & $\operatorname{IncX} 1$ & MPFT & MOBQ & blaTEM-52B & - & Mattila et al. 2017 \\
\hline \multirow[t]{2}{*}{ E. coli $\mathrm{HMS} 174(\mathrm{pECl} 6)^{\text {RifR, AmpR }}$} & pEC16p11 & IncIl & MPFF & MOBP & blaSHV-12 & - & Mattila et al. 2017 \\
\hline & $\begin{array}{c}\text { pEC16p12 } \\
\text { (non-conjugative } \\
\text { mobilizable) }\end{array}$ & ColRNAI & - & MOBP & - & - & Mattila et al. 2017 \\
\hline$\underset{\text { TetR, KanS }}{\text { E. coli HMS } 174 \text { (RP4-s.g.2) }}{ }^{\text {RifR,AmpR, }}$ & RP4 & $\operatorname{Inc} P-1 \alpha$ & MPFT & MOBP & - & - & $\begin{array}{l}\text { Smillie et al. 2010, Garcillán- } \\
\text { Barcia et al. } 2011\end{array}$ \\
\hline E. coli HMS 174 (pET24) ${ }^{\text {RifR, KanR }}$ & $\begin{array}{c}\text { pET24 } \\
\text { (non-conjugative) }\end{array}$ & - & - & - & - & - & - \\
\hline
\end{tabular}

Table 2: Average conjugation rate of beta-lactam resistance from each strain. Statistically significant differences are shown in bold italic letters behind the values (Two-way ANOVA, $\mathrm{p}<0.01)$.

\begin{tabular}{lccc}
\hline & $\begin{array}{c}\text { Mean } \\
\text { CFU/ml }\end{array}$ & SE & $\begin{array}{c}\text { Statistically } \\
\text { different } \\
\text { groups }\end{array}$ \\
\hline E. coli HMS174 (pEC3) & $1.65 \mathrm{E}+07$ & $4.61 \mathrm{E}+06$ & $\boldsymbol{a}$ \\
E. coli HMS174 (pEC13) & $5.67 \mathrm{E}+08$ & $9.87 \mathrm{E}+07$ & $\boldsymbol{b}$ \\
E. coli HMS174 (pEC14) & $1.63 \mathrm{E}+05$ & $2.90 \mathrm{E}+04$ & $\boldsymbol{a}$ \\
E. coli HMS174 (pEC15) & $4.79 \mathrm{E}+07$ & $3.55 \mathrm{E}+06$ & $\boldsymbol{a}$ \\
E. coli HMS174 (pEC16) & $2.11 \mathrm{E}+07$ & $3.52 \mathrm{E}+06$ & $\boldsymbol{a}$ \\
E. coli HMS174 (RP4) & $1.26 \mathrm{E}+09$ & $1.12 \mathrm{E}+08$ & $\boldsymbol{c}$
\end{tabular}


Table 3. Summary of plasmid dynamics in different ecological settings.

\begin{tabular}{|c|c|c|c|c|c|c|c|c|c|c|}
\hline Treatment & pEC3pl1 & pEC3pl2 & pEC13 & pEC14pl1 & pEC14pl3 & $\begin{array}{l}\text { pEC14pl2+ } \\
\text { pEC15pl1 }\end{array}$ & pEC15pl2 & pEC16pl1 & pEC16pl2 & RP4 \\
\hline $\mathbf{C}$ & $\begin{array}{l}\text { Increase then } \\
\text { decrease }\end{array}$ & $\begin{array}{l}\text { Decrease and } \\
\text { disappear }\end{array}$ & $\begin{array}{l}\text { Decrease and } \\
\text { disappear }\end{array}$ & $\begin{array}{l}\text { Decrease and } \\
\text { disappear }\end{array}$ & $\begin{array}{l}\text { Increase then } \\
\text { decrease }\end{array}$ & $\begin{array}{ll}\begin{array}{l}\text { Decrease } \\
\text { disappear }\end{array} & \text { and } \\
\end{array}$ & Persist & Persist & Persist & $\begin{array}{l}\text { Decrease al } \\
\text { disappear }\end{array}$ \\
\hline CA & $\begin{array}{l}\text { Increase then } \\
\text { decrease }\end{array}$ & $\begin{array}{l}\text { Decrease and } \\
\text { disappear }\end{array}$ & $\begin{array}{l}\text { Decrease and } \\
\text { disappear }\end{array}$ & $\begin{array}{l}\text { Decrease and } \\
\text { disappear }\end{array}$ & $\begin{array}{l}\text { Increase then } \\
\text { decrease } \\
\text { /Decrease and } \\
\text { disappear }\end{array}$ & Persist & Persist & $\begin{array}{l}\text { Decrease and } \\
\text { disappear }\end{array}$ & Persist & $\begin{array}{l}\text { Decrease al } \\
\text { disappear }\end{array}$ \\
\hline $\mathbf{C M}$ & $\begin{array}{l}\text { Increase then } \\
\text { decrease }\end{array}$ & $\begin{array}{l}\text { Decrease and } \\
\text { disappear }\end{array}$ & $\begin{array}{l}\text { Decrease and } \\
\text { disappear }\end{array}$ & $\begin{array}{l}\text { Decrease and } \\
\text { disappear }\end{array}$ & $\begin{array}{l}\text { Increase then } \\
\text { decrease }\end{array}$ & Persist & Persist & $\begin{array}{l}\text { Decrease and } \\
\text { disappear }\end{array}$ & Persist & $\begin{array}{l}\text { Decrease al } \\
\text { disappear }\end{array}$ \\
\hline CMK & $\begin{array}{l}\text { Increase then } \\
\text { decrease }\end{array}$ & Persist & Persist & $\begin{array}{l}\text { Decrease and } \\
\text { disappear }\end{array}$ & $\begin{array}{l}\text { Decrease and } \\
\text { disappear }\end{array}$ & Persist & Persist & $\begin{array}{l}\text { Decrease and } \\
\text { disappear }\end{array}$ & $\begin{array}{l}\text { Decrease and } \\
\text { disappear }\end{array}$ & $\begin{array}{l}\text { Decrease al } \\
\text { disappear }\end{array}$ \\
\hline CMKA & $\begin{array}{l}\text { Increase then } \\
\text { decrease }\end{array}$ & Persist & $\begin{array}{l}\text { Increase then } \\
\text { decrease }\end{array}$ & $\begin{array}{l}\text { Decrease and } \\
\text { disappear }\end{array}$ & $\begin{array}{l}\text { Decrease and } \\
\text { disappear }\end{array}$ & Persist & Persist & $\begin{array}{l}\text { Decrease and } \\
\text { disappear }\end{array}$ & $\begin{array}{l}\text { Decrease and } \\
\text { disappear }\end{array}$ & $\begin{array}{l}\text { Decrease al } \\
\text { disappear }\end{array}$ \\
\hline
\end{tabular}

Table 4. Persistence of different mobility and mating pair formation classes.

\begin{tabular}{|c|c|c|c|c|c|c|c|}
\hline \multirow{3}{*}{$\begin{array}{c}\text { Treatment } \\
\text { C }\end{array}$} & \multicolumn{2}{|c|}{ Mobility } & \multirow{3}{*}{$\begin{array}{c}\text { p- } \\
\text { value }\end{array}$} & \multicolumn{3}{|c|}{ Mating pair formation } & \multirow[t]{2}{*}{ p-value } \\
\hline & MOBP & MOBF & & MPFI & MPFT & MPFF & \\
\hline & Most plasmids persisted & $\begin{array}{l}\text { All but one } \\
\text { plasmid } \\
\text { disappeared }\end{array}$ & & Most plasmids persisted & $\begin{array}{l}\text { Most plasmids } \\
\text { persisted }\end{array}$ & $\begin{array}{l}\text { Most plasmids } \\
\text { persisted }\end{array}$ & 0.919 \\
\hline $\mathbf{C A}$ & Most plasmids persisted & $\begin{array}{l}\text { Most plasmids } \\
\text { decreased and } \\
\text { disappeared }\end{array}$ & 0.001 & All plasmids persisted & $\begin{array}{ll}\text { Most plasmids } & \\
\text { disappeared } & \end{array}$ & $\begin{array}{l}\text { Half of the } \\
\text { plasmids } \\
\text { disappeared }\end{array}$ & $\leq 0.01$ \\
\hline $\mathbf{C M}$ & Most plasmids persisted & $\begin{array}{l}\text { All but one } \\
\text { plasmid } \\
\text { disappeared }\end{array}$ & 0.005 & All plasmids persisted & $\begin{array}{lr}\text { Most } & \text { plasmids } \\
\text { decreased } & \text { and } \\
\text { disappeared } & \end{array}$ & $\begin{array}{l}\text { Most plasmids } \\
\text { decreased and } \\
\text { disappeared }\end{array}$ & $\leq 0.01$ \\
\hline CMK & Most plasmids persisted & $\begin{array}{l}\text { One out of three } \\
\text { plasmids } \\
\text { persisted }\end{array}$ & 0.226 & All plasmids persisted & All plasmids persisted & $\begin{array}{l}\text { Most of the } \\
\text { plasmids } \\
\text { disappeared }\end{array}$ & $\leq 0.01$ \\
\hline CMKА & Most plasmids persisted & $\begin{array}{l}\text { Most plasmids } \\
\text { persisted }\end{array}$ & 0.142 & All plasmids persisted & All plasmids persisted & $\begin{array}{l}\text { Most plasmids } \\
\text { disappeared }\end{array}$ & $\leq 0.01$ \\
\hline
\end{tabular}


Table 5. Treatments and their conditions

\begin{tabular}{|c|c|c|}
\hline \multicolumn{2}{|r|}{ Treatment } & \multirow{2}{*}{$\begin{array}{l}\text { Media } \\
5 \mathrm{ml} \mathrm{LB} \text { medium }\end{array}$} \\
\hline $\mathbf{C}$ & Plasmid community without selection & \\
\hline CA & Plasmid community under lethal $\beta$-lactam selection & $5 \mathrm{ml} \mathrm{LB}+150 \mu \mathrm{g} / \mathrm{ml}$ ampicillin \\
\hline $\mathbf{C M}$ & $\begin{array}{l}\text { Plasmid community with a constant migration of } \\
\text { plasmid-free hosts }\end{array}$ & $\begin{array}{l}5 \mathrm{ml} \mathrm{LB}+5 \mu \mathrm{l} \text { plasmid-free } \\
\mathrm{HMS} 174 \mathrm{o} / \mathrm{n} \text { culture }\end{array}$ \\
\hline CMK & $\begin{array}{l}\text { Plasmid community with a constant migration of } \\
\text { higher fitness plasmid-free hosts }\end{array}$ & $\begin{array}{l}5 \mathrm{ml} \mathrm{LB}+2.5 \mu \mathrm{g} / \mathrm{ml} \text { kanamycin }+5 \\
\mu 1 \mathrm{HMS} 174(\mathrm{pET} 24) \mathrm{o} / \mathrm{n} \text { culture }\end{array}$ \\
\hline CMKA & $\begin{array}{l}\text { Plasmid community with a constant migration of } \\
\text { higher fitness plasmid-free hosts under lethal } \beta \text { - } \\
\text { lactam selection }\end{array}$ & $\begin{array}{l}5 \mathrm{ml} \mathrm{LB}+150 \mu \mathrm{g} / \mathrm{ml} \text { ampicillin }+ \\
2.5 \mu \mathrm{g} / \mathrm{ml} \text { kanamycin }+5 \mu 1 \\
\text { HMS174 (pET24) o/n culture }\end{array}$ \\
\hline
\end{tabular}




\section{FIGURE LEGENDS}

Figure 1. The experimental design of the serial culture experiment. Ampicillin was used for betalactam and kanamycin for aminoglycoside. The cultures were refreshed 41 times $(\mathrm{N}=4 /$ treatment $)$.

Figure 2. Maximum growth rates and yields of each individual strain (A and $\mathrm{C}$ ) and communities under different treatments at the starting and end-point of the experiment (B and D). Statistical difference of growth rates and yields was determined using two-way ANOVA $(\mathrm{p}<0.05)$. Growth rate for the CMK communities at starting point was the highest $(\mathrm{p}<0.01,2$-way ANOVA, posthoc: Tukey HSD) whereas no difference in the growth rate was shown between C, CA, and CMKA ( $\mathrm{p}=0.067,2$-way ANOVA, post-hoc: Tukey HSD). At the end-point, significant difference was observed among all treatments ( $p<0.01,2$-way ANOVA, post-hoc: Tukey HSD) (B). Yields of the communities at the end point were significantly higher than the starting point between all treatments ( $\mathrm{p}<0.01,2$-way ANOVA, post-hoc: Tukey HSD) (D).

Figure 3. Prevalence of plasmids under different conditions as normalized with the gene for $16 \mathrm{~S}$ ribosomal RNA over 42 cycles of the serial culture experiment. A) Four replicates of C “community”; B) Four replicates of CA “community with antibiotics" (beta-lactam ampicillin).

Figure 4. Prevalence of plasmids under different conditions as normalized with the gene for $16 \mathrm{~S}$ ribosomal RNA over 42 cycles of the serial culture experiment. A) Four replicates of CM "community with migration of plasmid-free hosts"; B) Four replicates of CMK "community with migration of high-fitness plasmid-free hosts"; C) Four replicates of CMKA "community with antibiotics and migration of high-fitness plasmid-free (antibiotic sensitive) hosts".

Figure 5. Observed mutations in plasmids after 42 cycles in the serial culture experiment $(\sim 320$ generations). Only plasmids with mutations are shown. The black dots mark the mutation region and its frequency; the bigger the black dot, the higher mutation frequency (for exact values, see Supplementary data 1$)$.

Figure 6. Observed mutations in the host chromosomes obtained from the community after 42 cycles in the serial culture experiment ( $\sim 320$ generations). Mutations in non-coding regions are not 
bioRxiv preprint doi: https://doi.org/10.1101/2021.08.02.454727; this version posted August 2, 2021. The copyright holder for this preprint (which was not certified by peer review) is the author/funder. All rights reserved. No reuse allowed without permission.

labelled. The black dots mark the mutation region and its frequency; the bigger the black dot, the higher mutation frequency (see Supplementary data 1). 
bioRxiv preprint doi: https://doi.org/10.1101/2021.08.02.454727; this version posted August 2, 2021. The copyright holder for this preprint (which was not certified by peer review) is the author/funder. All rights reserved. No reuse allowed without permission.

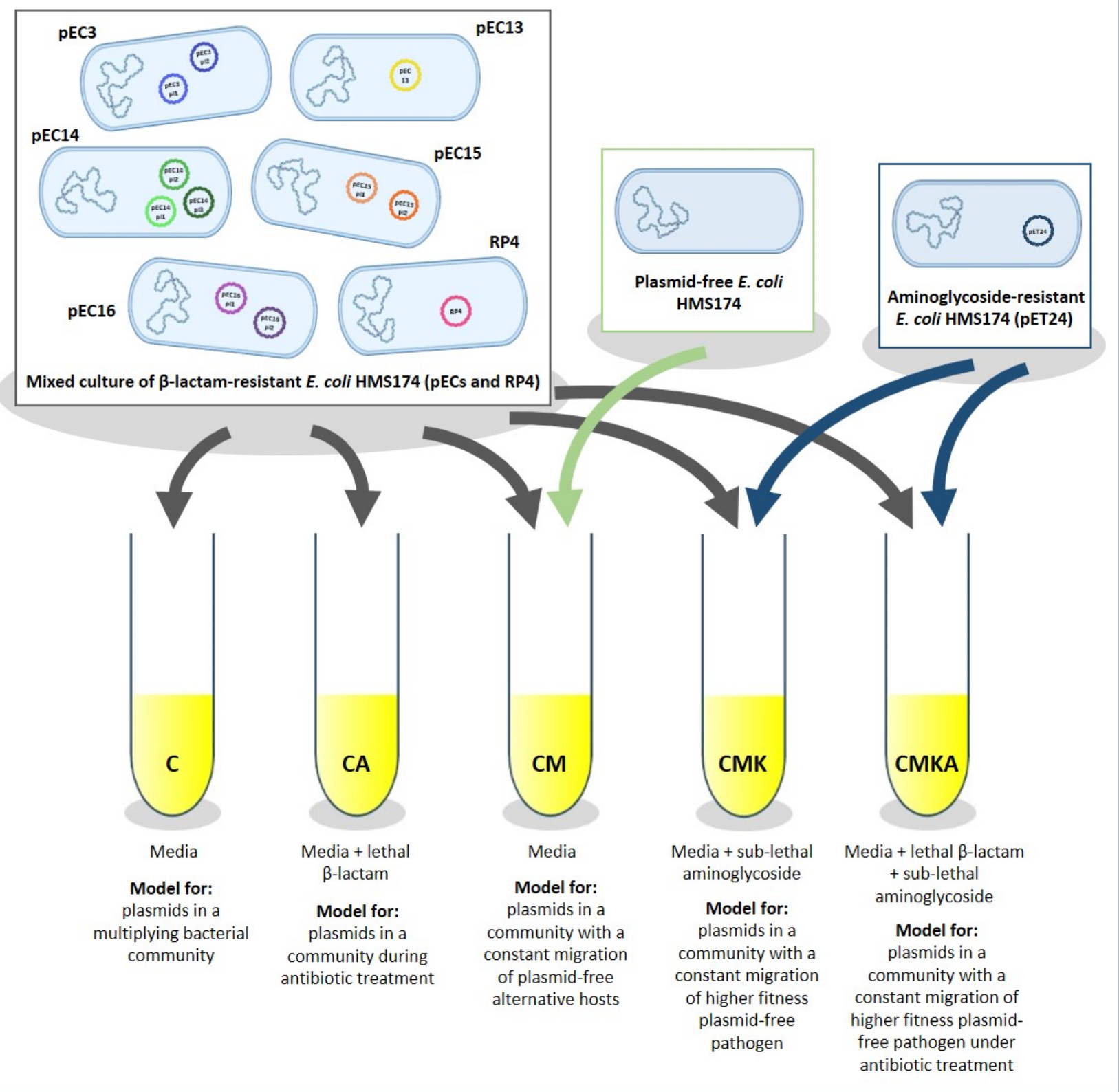


bioRxiv preprint doi: https://doi.org/10.1101/2021.08.02.454727; this version posted August 2, 2021. The copyright holder for this preprint (which was not certified by peer review) is the author/funder. All rights reserved. No reuse allowed without permission.

A 0.014

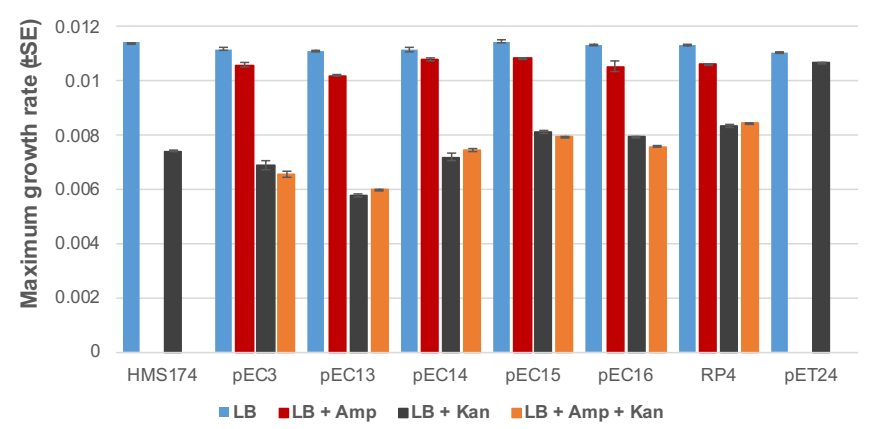

C

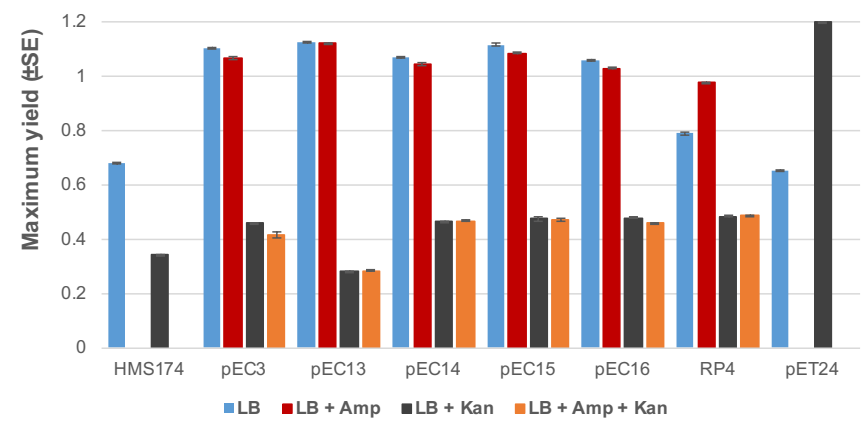

B

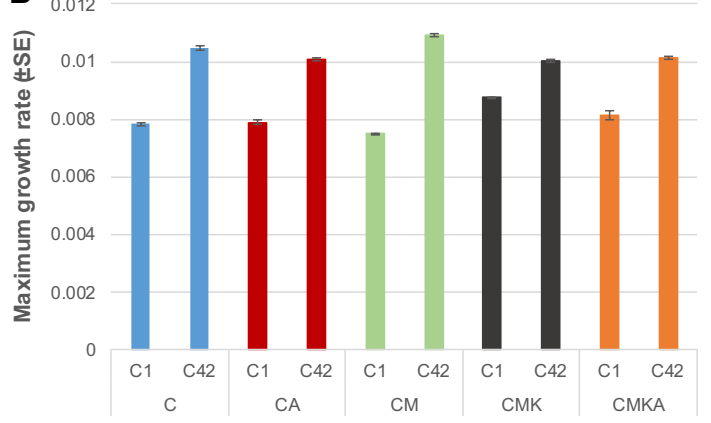

D

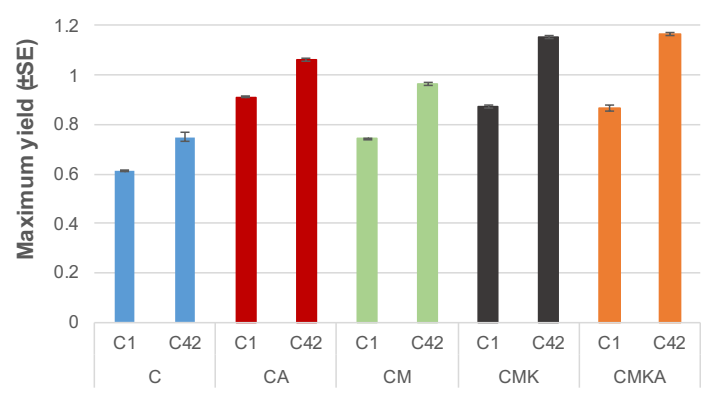


bioRxiv preprint doi: https://doi.org/10.1101/2021.08.02.454727; this version posted August 2, 2021. The copyright holder for this preprint (which was not certified by peer review) is the author/funder. All rights reserved. No reuse allowed without permission.

A

C

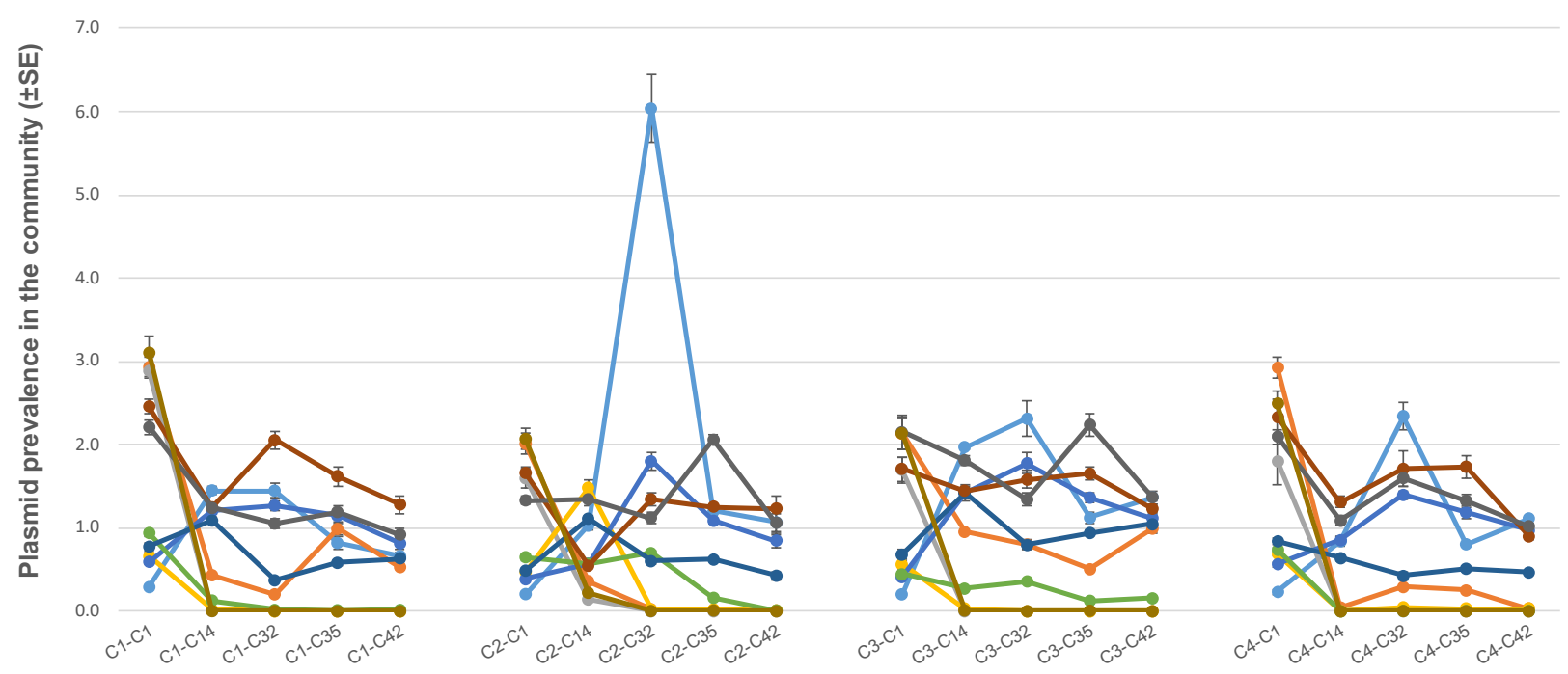

B

CA

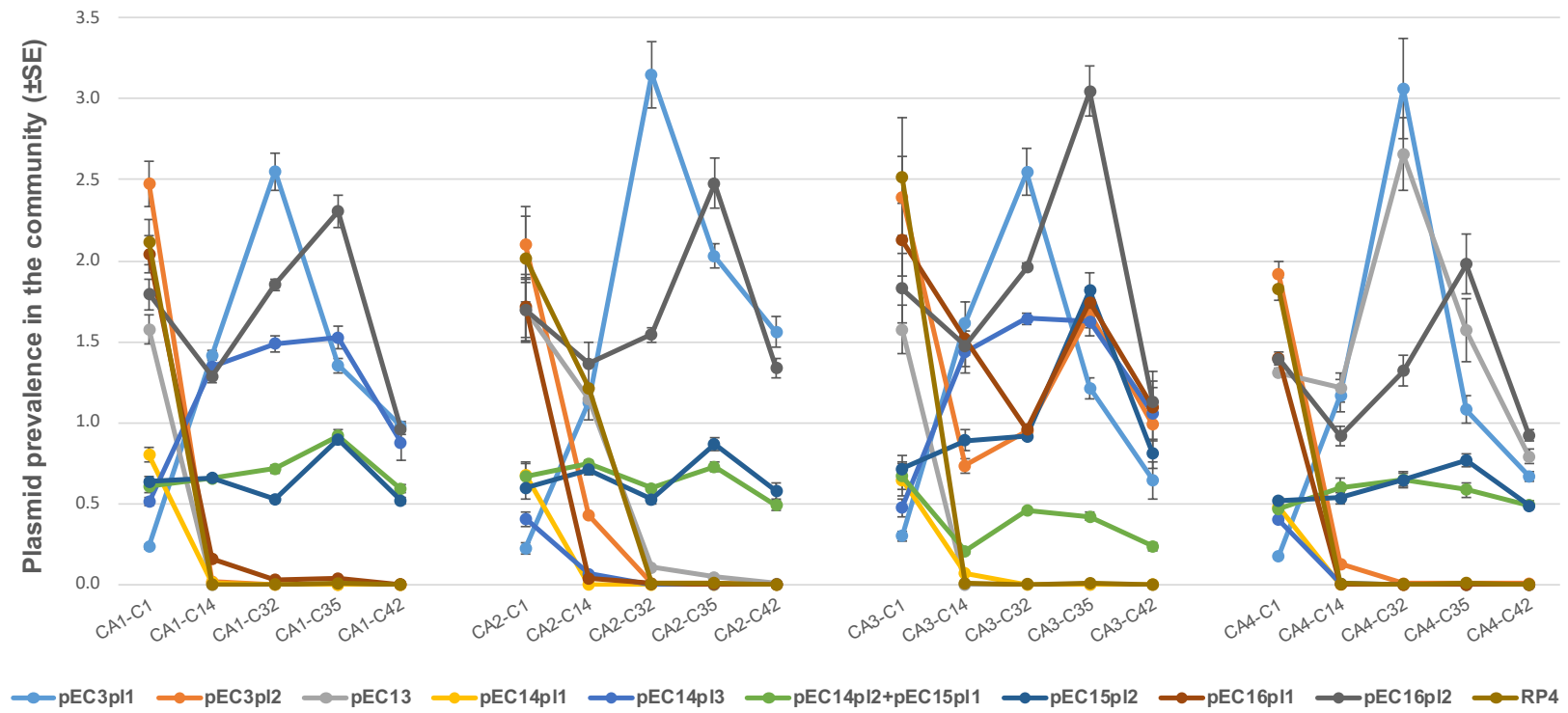


bioRxiv preprint doi: https://doi.org/10.1101/2021.08.02.454727; this version posted August 2, 2021. The copyright holder for this preprint (which was not certified by peer review) is the author/funder. All rights reserved. No reuse allowed without permission.

A

$\mathrm{CM}$
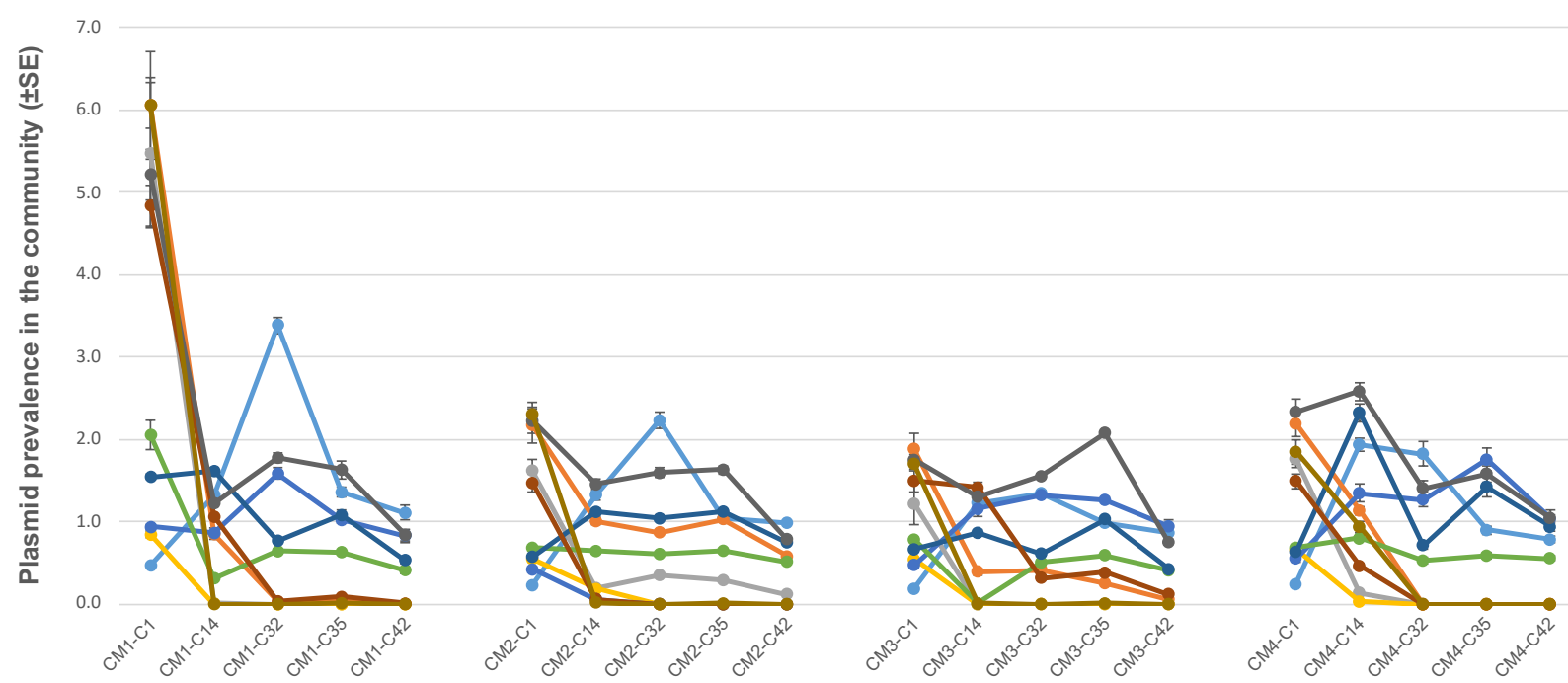

B

CMK

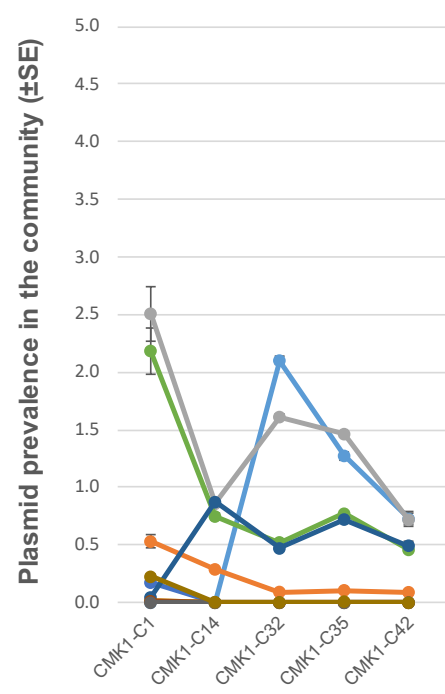

C

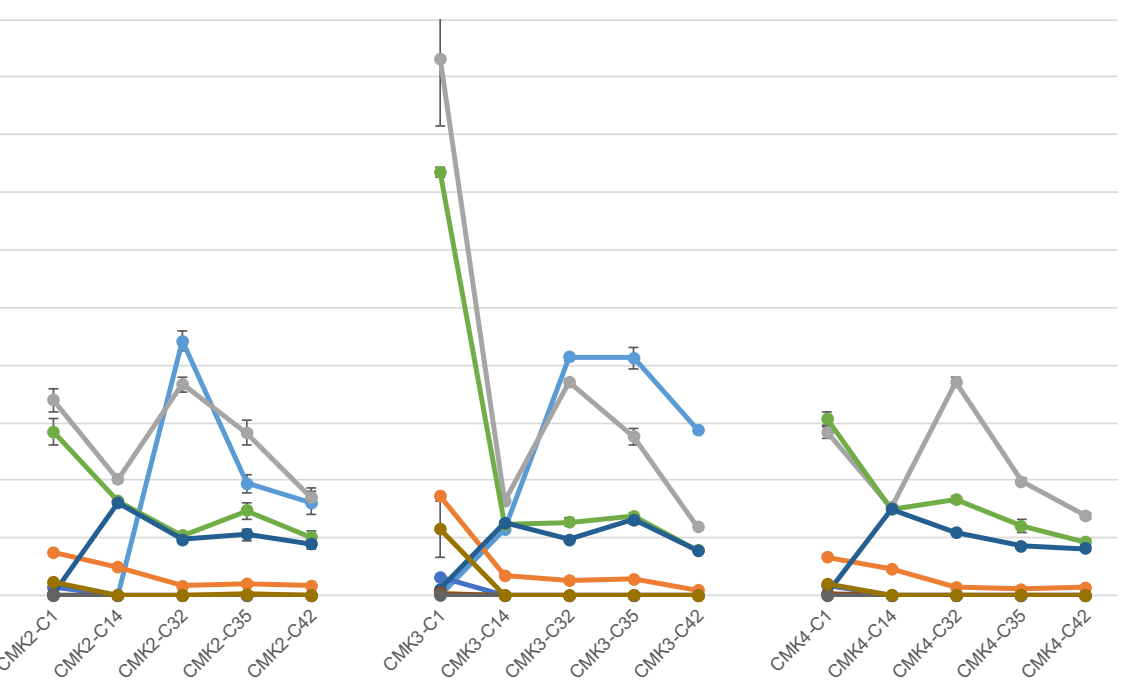

CMKA
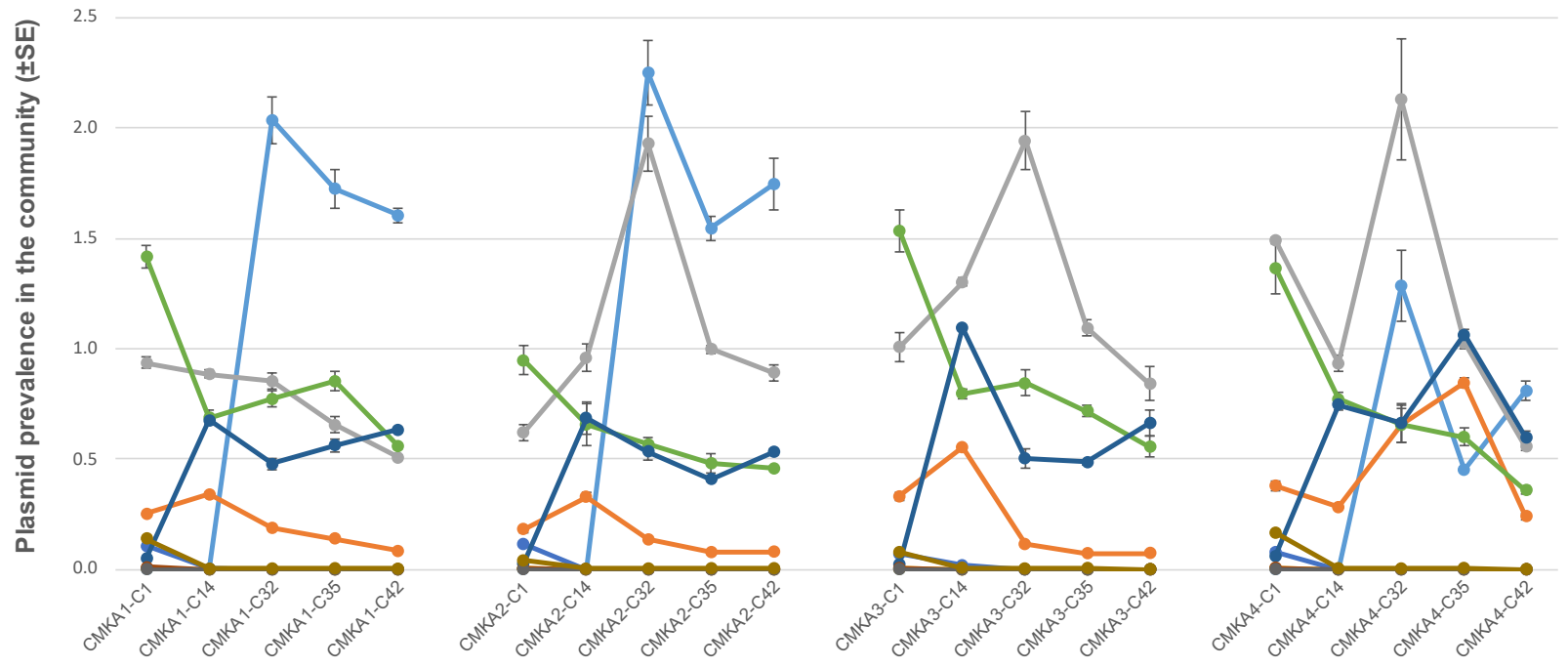

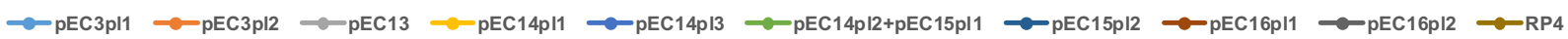


bioRxiv preprint doi: https://doi.org/10.1101/2021.08.02.454727; this version posted August 2, 2021. The copyright holder for this preprint (which was not certified by peer review) is the author/funder. All rights reserved. No reuse allowed without permission.
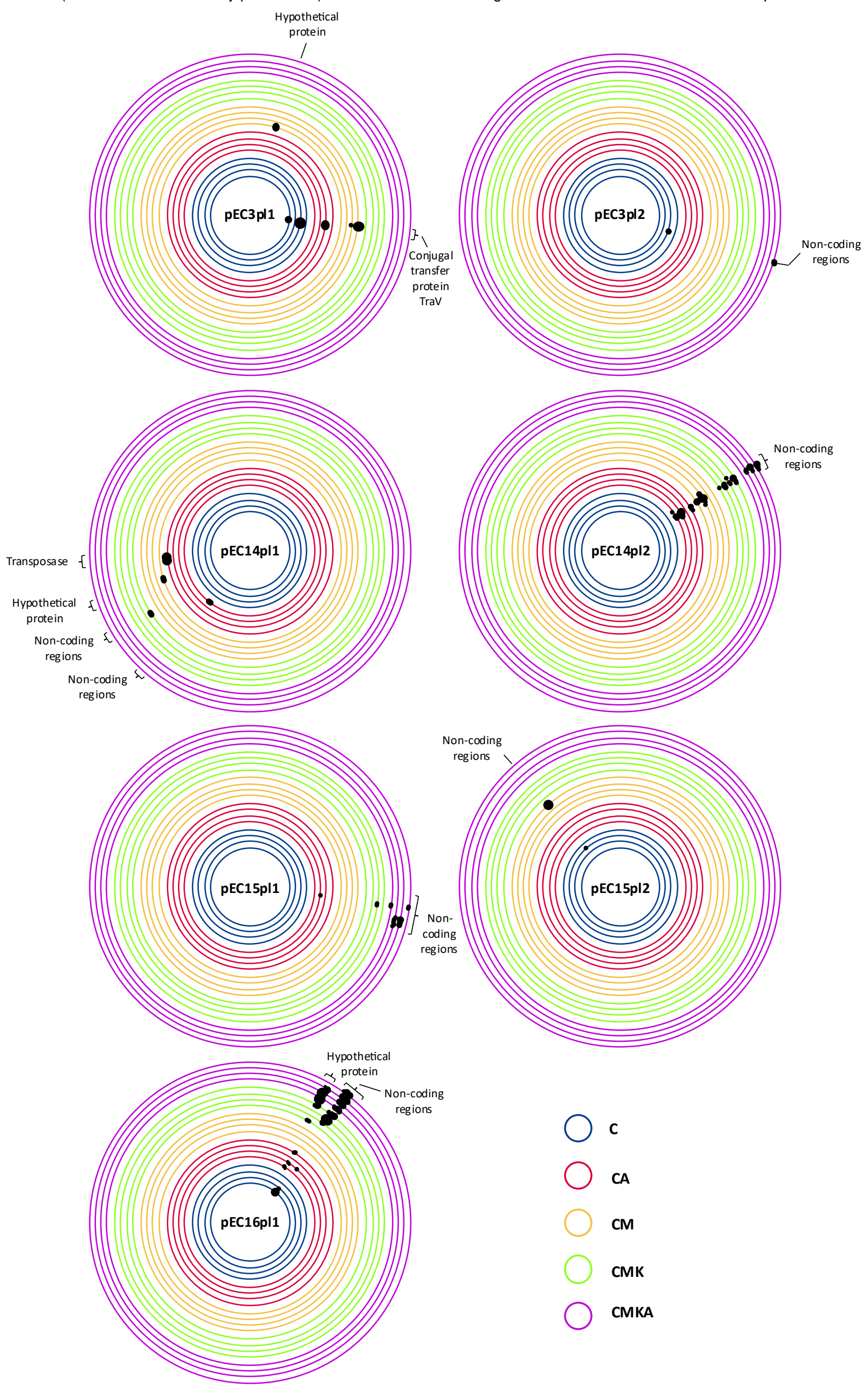
bioRxiv preprint doi: https://doi.org/10.1101/2021.08.02.454727; this version posted August 2, 2021. The copyright holder for this preprint (which was not certified by peer review) is the author/funder. All rights reserved. No reuse allowed without permission.

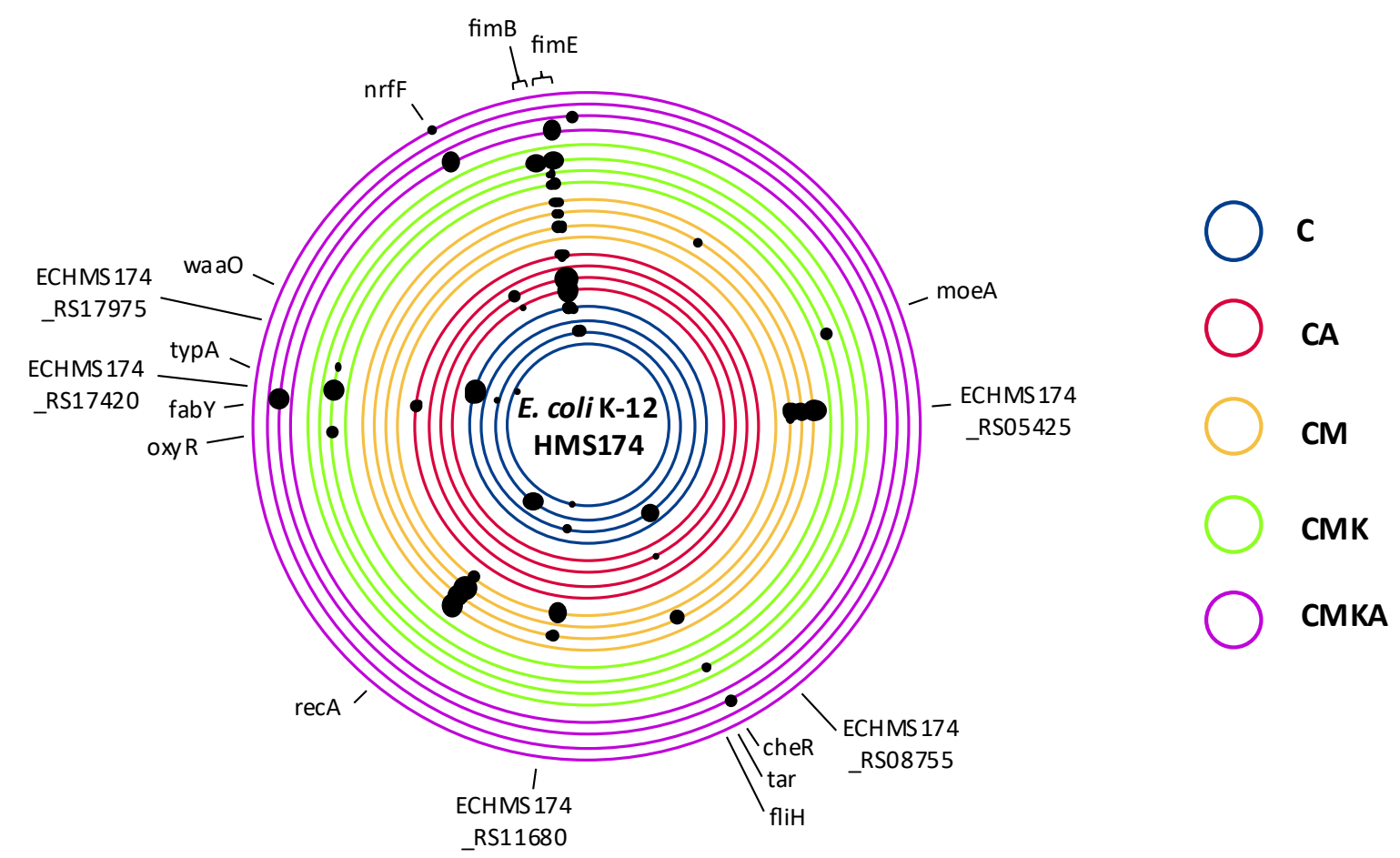

